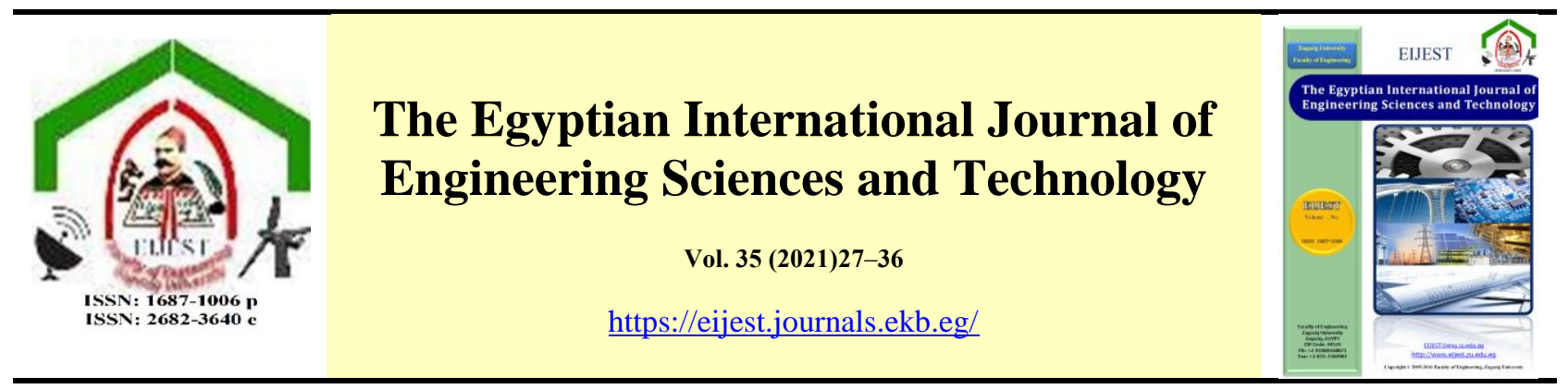

\title{
The Just City: A Socio - Economic and Environmental Perspective.
}

\author{
Tarek Abou-Zekry, Ahmed Elmenshawy, Asmaa Mubarak*
}

Deprtment of Architectural Engineering,Faculty of Engineering,Zaqaziq university,Zaqaziq City,Egypt

\begin{tabular}{l}
\hline A R T I C L E I N F \\
\hline Keywords: \\
Just city \\
Social justice \\
Economic justice \\
Environmental justice \\
Justice measurements.
\end{tabular}

\section{Introduction}

This paper explores injustice in urban communities. Where lower income classes are obliged to bear unacceptable level quality of life, while higher income groups are enjoying all urban development benefits. These disparities among these communities are apparent in housing stock, population density, little area of roads network, small areas and low quality of public spaces, less job opportunities, low per capita income, and overall aspects of bad quality of life.

These inequalities extend to their basic needs of public services such as education, healthcare, infrastructure, access to open spaces and public transportation. These shortages become more problematic in poor communities where development fruits hardly provide primary needs instead of improving welfare and quality of life [1]. Africa comes at the top of distributional disparity indicators $(52 \%$ African countries suffer from injustice) [2]. Quality and quantity of public services differs from one area to another within the same city. These differences are the result of capitalism and privatization policies of both education and health care services. Government policies accentuate these differences because it gives a priority to the capital cities and the areas of high-income groups to allocate its investments. We know that development, urban renovation and services supply happen in phases

* Corresponding author. Tel.: 01145374040

E-mail address: aamelsayed@zu.edu.eg. 
and stages. So, some parts of cities have higher levels of services than others. This makes disparities in quality of life between affluent areas and low-income ones within the same city. These disparities can create social problems like weak social bonds, social segregation, conflicts, alienation, high crime rates, poverty, unemployment and illiteracy. Other urban problems can be generated like urban injustice among adjacent areas, unliveable urban environment, informal communities, slums and other urban disasters [1].

Justice within a city means that every citizen in the community should have choices in the process of their need's sufficiency like daily needs, legal rights and access to essential services [3].

Most people in developing countries are marginalized and cannot realize their rights of living. Reasons are many, e.g., wealth, resources and power are concentrated in the hands of small percentage of citizens. They use their influence for making more profits and fulfil their interests. In a free market community, everyone searches to achieve his interest. In these unjust societies, people of power and high-income classes can get their rights. While low-income groups, who are marginalized and excluded, cannot find access to basic services and facilities, they do not have any political rights, have no role in the state administration level or rightful status in the society [4].

Urban physical features are a mirror of social, economic, environmental and other characteristics of the society. As a result of urban injustice, there are several social, economic and environmental problems threatening these communities. So, if we want to improve our society's stability and prosperity, we should solve our urban problems, specially urban injustice to move towards a more just world.

\subsection{The Research Question}

What are the economic, social and environmental dimensions of just city?

\subsection{Methodology}

To answer this question, this paper adopts an inductive theoretical research methodology. It makes use of making content analysis while reviewing the literature and studying the historical evolution of just city concept. It approaches the just city theory from three perspectives: social, economic and environmental ones. This research makes use of secondary data in the analyses and in the research design.

\subsection{The aim of this Paper}

This paper aims to introduce the definition of just city concept from multi-disciplinary approach. Exploring just city theory and illustrating the reasons and consequences of urban injustice. It searches for an answer to the question of how to reduce urban injustice. It seeks for applying justice in our cities. And it tries to extract some criteria to judge urban justice within a city to identify areas of sever injustice.

\subsection{Historical approach to justice as a concept in a city}

Justice, like other philosophical concepts, was found by early Greek philosophers. Introduced by arguments of Plato and Aristotle: it is a must that all social classes in a community have the same social advantages. The discussions have been continued to our contemporary scientists that: everybody should have access to all basic services. These services include natural rights like living, freedom, lifestyle and so on that people must have by birth. The functionalisms accepted that there are differences and imbalances among social classes in the society as long as rights, opportunities, advantages and obligations are fairly distributed to all people. These acceptable imbalances affect people welfare not their essential needs [5].

Justice concept historically found in Athens' records. Plato was the most important philosopher who presented the concept of justice. He searched for justice and perfections in society to create a just city. He believed that justice is the only key for solving the problems of his community [4]. Philosopher Socrates explained justice from political perspective, when argued that justice contains power distribution and quality of cities based on actions of its inhabitants. He also illustrated the important role of public sector to create justice within a city and in people life [6].

\subsection{Literature Review: "the just city"}

The contemporary debates about justice within a city has appeared in 1960s, when political urbanist found that decision makers did not give attention to minority residents like low-income people, female, and so on. As a result, they did not only exclude them from their policies but also, they harmed them. Particularly they are interested in businesses rather than needs of cities' residents. They gave priority to secondary activities such as sports and tourism while ignoring primary ones like schools, industries and public services in general. As a result of these critiques, just -city theory 
appeared. Just city is the city where we find public investments, policies and laws generate fair outcomes for all, instead for those who have already better life.

Policies are the main reasons for urban injustice in cities. It harm people who have already the least benefits, excluding them from any rights or facilities, while preferring other residents who have already the most benefits, e.g. housing stock, employment, public services and public urban spaces [7]. Fainstein [6] argues that, just city concept contains many values contributing to create public spaces, housing, job opportunities, and social programs. These values should be mixed with other changing movements of social perception and the meaning of collective good.

This paper is based on contemporary thoughts of scientists like Fainstein and Campbell [6] who presented their writings in urban planning. Their arguments are based on theory and practice of justice in cities. They depended on the previous writings of Friedrich Engels (1872), Ebenezer Howard's (1898), Davidoff (1965). All of these arguments helped in finding answers to the questions of: how can policies create better cities for all? and how can these policies be evaluated?

These questions stick to the new social movements of justice, which call for justice not equality. These movements struggle for getting material goals like economic redistribution and nonmaterial goals like opportunities and liberties. Most of these writings are interested not only in justice concept but also to understand justice theory in practical way. To do so, we may present John Friedman's meaning of justice [6]. He interested in the very physical issues of housing, health care, wages, and social welfare as the four bases of the good just city. He saw that the civil society organizations' role is to support these four bases in a democratic society.

Also, to realize just city we have to consider Henri Lefebvre [6] and what he named right to the city. He focused on participation of residents not only in having urban space but also in producing it by participation in the decision-making process. It means our right to urban space usage and participate in creating it politically and socially. This participation makes society institutions and non-profit organizations cooperate and call for justice from its social, economic and environmental dimensions. These organizations call for the right to land and for just housing, which could produce sustainable and just communities that include political and cultural spaces. Urban justice debates discuss important questions made by urbanists. These questions are about equity, democracy, and differences. Fainstein [6] argues that to produce public spaces, housing, economic and social development is to move towards a more just city.
So, we need some guide values like clear definitions and notions of justice and social inclusion.

John Rawls [7] in his foundational work, "Theory of Justice" (1971), called for fair distribution of primary goods. His work discussed the relation between quality and justice. He began by defining an individual position for everyone who belongs to any society. This original position means that every citizen acts fairly and as a result of this, he could build the bases of just society. Liberty is Rawls's first principle and difference is his second one, which means that everyone should have fair opportunity and if there is any inequality in the society, the least-advantaged citizens should be the benefiter.

Rawls [8] emphasized individual and societal concepts that related to democracy. Free citizens live in a fair society where they find fair cooperation of the individuals' mutual advantages. In his human community, residents share benefits and socio-economic burdens fairly. He recognized that the development based on difference and welfare does not succeed in creating justice, as the process of resources production is controlled by a small group. As a result of this policy, number of disadvantaged citizens, that need support would be increased. For example, the welfare developments in Northern Europe-where unemployed people from immigrant backgrounds are supported through national income- fail in putting down their anger and make them feel justice, that validates Rawls' argument. Habermas [7] brought into concepts of rationality, truth-telling, and democracy; he assumed that debates and participation in the decision-making process will take us to the best decision and just results.

\section{- Justice definition}

To define justice, the verse concept of injustice should be firstly understood. Marx [7] thought that injustice is the result of the relations of production not distribution. So, we cannot change this condition without changing production relations and reshaping it. So as to produce working class that knows its political duties and rights. As a result of this, social transformations can be made that provide each class with its needs. Justice aims to create peaceful society, where everyone can live in peace. It is required to demolish enmity and social conflicts. Harvey [7] argues that just planning and decision-making must seek to get rid of social exclusion, domination, individualism and violence. Although Harvey defined injustice problem, he did not suggest any solution.

\section{- Appearance and Evolution of "Just city concept".}

The neoliberal debates of justice, utopian city, and the right to the city ensure the importance of merging 
both of political philosophic and political economic with justice understanding. Susan Fainstein [6] who introduced this idea to give urban planner a model which deals with spatial and social injustice, that appeared as a result of capitalism". She developed political economic form; she labeled her model "Just City" which aims to realize social justice. She applied values from philosophical justice notions that lead to create the "good city". This theory of Just City tries to give alternative to paradigms of Habermasian communicative rationality (The Communicative Model) and the physically determinist view of urban social life (The New Urbanism).

\section{Definitions}

following the content analysis of the topic, the paper illustrates some definitions which are forming the "just city concept":

\subsection{The city}

The city is the space whose size is suitable for both government to control and people to practice their political rights [6]. It has a great effect on creating our interactions with each other and with our environment. Policy makers should be aware of and give more attention to the city and its important role in shaping society. We can understand city definition through several dimensions. From economic perspective the city is like a machine of economic development, from social perspective it shapes our perceptions and social relations in an urban environment, and the city has a great effect from environmental perspective [9]. In the past, city was the place of production, but Castells [7] did not define cities as the spatial forms that is responsible for production, but he considered it as the place where people consume goods that make up for their labor wages shortage.

\subsection{Justice and injustice}

We have to understand roots of injustice to realize justice [9]. This concept appeared as a result of urbanization movement and its result of violence, insecurity, exploitation, and poverty. Through inequity in social, cultural, political, environmental and economic conditions which resulted in discriminations existing among people in race, class, gender and so on [6]. Injustice refers to unfair and inequality conditions in a community. Most developing communities suffer from injustice in many levels of society. On the other hand, most citizens in most developed communities are integrated and included in all processes of resources and power management [4]. Theoretically, justice is the product of deliberation, the concept of public participation is not sufficient to apply justice in policy making, but it can employ justice and define it as a criterion for evaluation. On the empirical level, justice definition changes from the idea of only distributing resources fairly to involve all social groups in society without exclusion [7].

\subsection{Just city}

When societies seek to achieve just city, they should develop their institutions to be able to deal with issues and reshape their resources to achieve their goals. So, when they search for just city, they should take into consideration means and aims together, policy and the aims of social movement and how to make a good public policy. Traditional notions of justice considered that to achieve just city, there should be economic development. And the New Urbanism Congress refers that to realize just city, communities should make smart growth and prevent sprawl. Theories are important, but justice needs to be applied in cities, in distributing resources and in changing traditional discussions. So, demands for equity will not be marginalized anymore and that will be a beginning to get rid of circumstances that marginalize people in the urban life and policy.

Scientists take just city theory from their point of view. They always try to ensure the importance of this theory and realize its implementations. Urgently equity needs to be achieved, fair distribution and differences respecting need to be applied, that will lead us to a new more just city for all people instead of social exclusion [6]. Just city, it is the city where difference is not only admitted but it is also recognized and respected. It is a city for all social classes and groups. For Rawls [7] just city could be realized only when there is just distribution of benefits and decreasing of disadvantages, this is the main stone of public policy. He asserted on getting rid of concentrations of wealth and power that will lead us to get near a utopian city, that does not mean stopping injustice but decreasing it. So, for Rawls, the evaluation criterion of urban policy is to give the most benefits to the marginalized people and the less advantaged ones. Just city is the city where there is fair outcome distribution because public regulation works for all instead of working for elite classes. By this, urban injustice can be minimized and making sure that disadvantaged people-who enjoy rights less than other elites- do not suffer anymore and enjoy their rights in a 
justly way. These rights include housing, employment, access to public spaces and other public services. So, just city concept should be understood and should be achieved to support the poor and minorities. Just City is a vision of the city based on institutions reshaping, wide problems rethinking, new deal with money flow movement and organizing. To realize these aims, goals, means, strategies and public policies should be put into consideration.

\subsection{Equity}

It refers to the fair distribution of both material and nonmaterial benefits and resources among people and urban spaces. This is happened as a result of proper public policy that does not distinguish among their citizens and does not work for people whose conditions are already better. Equity does not mean that everyone has the same treatment as equality but has appropriate treatment. Utilitarianism defines equity as a criterion which ensures that the majority of society could benefit [7].

Equity among generations also should be taken in consideration through moving towards a more sustainable just city. It faces lots of difficult decisions like resource usage, consumption and pollution. With making these decisions probably, the quality of urban life will be better for current and future generations. These societies that apply equity and have high level of social, economic and political equity, supply their citizens with more fair income distribution, liberties, political rights and higher literacy levels. That leads to higher quality of life where citizens share a common future. We can apply this principle within nations and also among them [10].

\subsection{Democracy}

It refers to integrate democratic participation in the decision-making process, urban governance and involvement of all citizens in the political life to fight exclusion, alienation and move towards a more just city [11].

\subsection{Good governance}

Developed countries started to depend on participation in decision-making processes within the civil society including stakeholders, organizations and citizens instead of depending only on governments. To support more freedom, liberties, creativity and knowledge according to Local Agenda 21 at the 1992. For sustainability and justice, good governance is very important. It supports citizen participation in decision- making and it must be good to be acceptable. It gives a priority to disadvantaged and less represented people instead of those who have already more benefits. And ensures that everyone is involved in the process of decision-making like women, the young, the elderly, marginalized people and minorities. As a result of this policy, we can move towards more just sustainable societies [10].

\subsection{Utopian city}

Utopian city concept is stick to just city one because utopia, good and justice are interchangeable concepts. These concepts have been developed through power and knowledge relations. For John Friedmann [7] if there is moral anger from injustice this means that we have a justice sense. When we want to achieve justice in cities, we should think about utopian thought as a material image to take steps that make us closer to just city. Marx [6] considered that utopians failed to show us how to apply their ends. Political philosophers argue that this is the task of others. Planners, policymakers, and political activists should respect theories, history and work within it, they cannot start from scratch. Utopian ideas give us models that we inspire, but they did not provide means to apply its principles in historical context.

People can create their history, but they cannot control with their circumstances like original positions, desired capabilities, ideal speech situations, and rights to the city. Utopia is the city that designed very well. Fainstein [6] called it "utopia of spatial form". It is the city where we can satisfy our needs if we cannot be happy, and it is a harmony community. For John Friedmann [7] there is a relation between utopian and just city. If we want to solve urban injustice problem in cities, we should have concrete perception and take actions based on utopian thinking to move towards a more just world and realize our goal.

\subsection{Sustainability}

To understand sustainability clearly, we should not consider it just as a green or environmental issue. It contains multi disciplines like environmental, social matters, economic opportunities and welfare that should be coordinated and considered when decisions are made. According to The Union's Sustainable Development Strategy, it means that environment and ecosystems should integrate with social, economic dimensions in the society. Sustainability seeks to provide everyone who lives in the same limits of environment with a better quality of life in a justly way for current residents and for the coming generations. It looks at human conditions and problems in a holistic way rather than other policies 
which present disconnected solutions to issues of humanity [10]. Its definition differs from social class's perception to another. For upper and middle class, it refers to green spaces for recreation and enjoying nature. For the poor, they search for their food, water to survive and they are always afraid of losing their land. So, to achieve sustainability, it should be integrated with social justice [12]. As a result of the rising idea which says that there is no sustainable development without justice [13].

According to The Aalborg Conference on European Sustainable Cities and Towns (May 1994), sustainable development cannot be achieved without applying social justice, sustainable economies and environmental sustainability. Mega [14] also ensured the importance of social justice in achieving sustainability and took it as a main condition for sustainable development. From this relation between Justice -specially environmental justice- and sustainability scientists extract a new concept, they called 'just sustainability'. Both concepts are developed together, and they are so closed, but the relationship between them is still insufficiently clear [10].

\section{Justice dimensions}

All justice aspects which include social, legal, political, spatial, climate, economic and environmental ones, require access to and fair distribution of public services, resources and opportunities for all [15]. Marcuse [7] considered that justice is a multidimensional concept, so "just city" cannot be realized through one perspective. Harvey argued that if we want to define justice, different dimensions should be taken into consideration like social, spatial, geographical, and historical frames. It is very difficult to find an abstract definition for justice but trying to develop a concept that all people can understand.

This paper discusses urban justice from triple bottom line (TBL) perspective that contains social, economic and environmental dimensions. Justice or sustainable development do not succeed with one of them. All dimensions should be integrated, balanced and coordinated among all society components. So, to achieve justice within a city from (TBL) perspective, social, economic and environmental dimensions of justice should be understood [16].

\subsection{For social justice}

The concept of Social Justice appeared in 1973 when Rawlsian tried to understand urban problems but they did not succeed in achieving their aim (social approach). Then Marx and Harvey [6] illustrated unjust spatial development as a result of capitalism. Harvey saw that justice needs changes that fight urban injustice, political dominance, and economic power in capitalism. Finally, he called for make other modes of production, consumption and participation which shape hierarchy of society's classes. All of these ideas discuss society' classes from single perspective, so we have to involve other identities as race, ethnicity, and gender. Social justice needs not only equity and involving people in society but also shaping social relations that organize people and shape their positions, experiences, ideologies, opportunities and perceptions in their society.

To achieve social justice, differences should be respected without exclusion or marginalization [7]. We can understand the definition of social justice through social conditions in unjust societies such as disparities and distinguishing among classes, genders, races, and so on. So, social justice principle needs to be applied to prevent these social inequalities [12]. When applying this principle, quality of individual life can be improved producing a socially just society [17]. Social justice is defined as the fair distribution of wealth and resources, that aims to give all citizens equal rights, economic welfare, dignity, freedom and support the feeling of citizenship and solidarity [5]. Social justice aims also to stop capital concentration in the hands of particular elite class, and the unjust social investment in human capital like education and labor to improve social conditions and quality of communities [12].

- How to achieve social justice?

Chapple [13] considered that, to achieve sustainable and equitable social development, traditional liberal approaches to plan for justice should be take into consideration. This is very essential approach in unjust communities where there are exclusion, social segregation and inequalities. Just societies must guarantee equal opportunities for all citizens. Life opportunities are not only services and jobs accessibility but also social capital creation, social participation, solidarity and citizenship.

\subsection{For environmental justice}

Like sustainability, environmental justice concept is not easy to be defined, it is problematized concept. Therefore, several definitions for it can be found. In the US, the Commonwealth of Massachusetts uses the following definition in its Environmental Justice Policy: Everyone augh to have equal environmental rights such as living in healthful and good environment, not 
exposing to pollution, enjoying protection equally, access to environmental benefits equally and being involved in environmental laws, regulations and policies. This concept contains two sides (involvement of all people) and (right to live in healthful and highquality environment). It considers that environmental justice policy should not only be concerned with the distribution of environmental threats (risks, pollution...), but also should be concerned with the achievement of environmental opportunities (a higher quality of life, a sustainable community...) [10].

To realize environmental justice, we have to understand why there is an environmental injustice? This happens because of free housing market which makes unequal distribution of environmental quality. Rich people can live in expensive community where parks, green spaces and clean air, but the poor cannot afford to live in this environment. So, they have no choice to live in such lower environmental conditions. Poor people not only expose to environmental problems but also, they cannot face these problems and its results. Because of little levels of education, income and profession as many scientific studies in public health have showed. So, the poor are the most disadvantaged from these bad environmental conditions, and this results in low quality of life that increases environmental injustice.

The European Charta of Environment and Health of the World Health Organization said that in 1989 everyone has the same environmental rights that lead to more amount of health and wellbeing. But indeed, it is unachievable because economic and production processes in cities affect environment around man badly. It causes many problems like traffic noise, air pollution, and unsuitable green spaces. Although we can hardly notice these economic processes, we cannot ignore their bad effect on both environment and human health that led to physical diseases, stress and sleeping disturbance which have a harmful effect on man health [18]. Overall, these minority communities have less access to highquality life, because of polluted air, congested living spaces and streets, relative inaccessibility to clean public spaces and beaches [9].

Faber [10] considered that environmental justice does not only refer to fair distribution of environmental risks, but it also means preventing risks producing from their resources. He explained that environmental justice is very closed to sustainability concept and very important for it. He opposes Dobson's idea that says that environmental justice has no relation with sustainability as it means sharing environmental risks fairly without stopping them. Faber's idea takes environmental justice as a political and social principle through social inclusion and the participation of NGOs and governmental institutions.

- How to move towards a more environmentally just city?

From all above, environmental justice has to be improved and quality of environment has to be distributed equally within areas in cities. So, planners should deal with multi sectors and take in consideration its relations with health and social issues. Firstly, cities that suffer from higher level of environmental problems have to be known. Then the local quality of environment should be improved through noise protection, traffic calming or greening of public spaces.

As a result of these actions, the rent in housing market will increase. So, we need to find solutions without creating financial burdens for residents. We should know that it is important for human health to protect the environment specially through rapid population increase and urban growth. As a result of these problems, risks concerned with environmental resources augh to be faced. So, urgent strategies must ensure that environmental justice should be achieved regardless economic conditions [18].

\section{- Dimensions of urban environmental justice}

Environmental justice has very effective dimensions, social and economic. Economists from 1960s illustrated that although upper classes are the main responsible for pollution as a result of their culture of consumption, they bear less expenses for environmental protection than lower classes. Few main elements distinguish urban environmental justice. These elements can be broken down into two categories:

- $\quad$ economic dimension: These elements deal with economic conditions, concerned with nature and regulations of land uses.

- $\quad$ social dimension: These elements deal with historical and social conditions, that different social groups face in the cities [9].

\subsection{For economic justice}

Everyone in the same country has the same rights as liberties, economic rights and other rights, that we should share fairly their disadvantages [6]. The principle of justice as fairness seeks to get rid of the concept of advantaged or disadvantaged in the society, from social and economic perspective. Through the process of natural outcomes and resource distribution. Everyone is similarly treated and there is no principle that 
distinguishes groups or work for their benefits, all citizens have the same relations to each other [19].

\section{Advantages of justice and disadvantages of injustice}

\subsection{Why justice?}

Inequality generates conflicts and destroys social peace within society classes. So, when societies try to create more peaceful communities and realize more quality of everyday life. They should firstly try to achieve justice within cities applying justice principles to create the just city and give a new just life for all social groups [6].

Achieving justice within a city is very important issue because it results in ideal distribution of resources and equality of allocating them, that can lead to economic growth. So, justice within a city must be given more attention to become a livable one. Justice is a very important value for communities and individuals. It makes nations more developed in social, economic, political, environmental and other aspects. As a result, it encourages innovation, development and economic growth [7].

For citizen, it strengthens the sense of citizenship and belonging to society. By justice, citizen has the chance to have a high level of life, that makes him a high standard one knowing his rights, duties and acts properly in his community. So, several problems can be gotten rid of like poverty, exclusion, illiteracy, unemployment, conflicts and crimes that destroy society [6].

\subsection{The shame of injustice}

More than half of the world population live under poverty line. The World Bank defines them as living on $\$ 1.90$ a day. Through these conditions hundreds of millions of people live in economic insecurity and they are worried about their constant salaries. Although the major of the poorest people in the world live in developing societies like India, Sub-Saharan Africa and rural China, there are tens of millions of poor people live in developed countries for example, in America 13\% of its population are poor (44 million people).

The poor in anyplace suffer from marginalization from society as a result of this, they are subjected to exploitation. Poverty is the result of inequality, and it is a form of injustice through unfair distribution of wealth; few rich people have most of the wealth, but the poor try to get the crumbs to survive. Poverty is not the only result of injustice but there are also many other problems. For example, poor people are subjected to homelessness, low levels of education, health care, low quality of housing and urban environment.

Although justice is a human right like freedom that is called for by the United Nations, we still suffer from injustice in our world. For example, it is unjust when the education level of child depends on his parent's wealth and other service like health care is determined according to the affordability of patient, so we urgently in need to get rid of injustice from its roots [20].

\section{Reasons, consequences of urban injustice and how to reduce it?}

\subsection{Reasons of urban injustice}

What creates injustice in societies is the way that determines the location of facilities and utilities based on considerations of their economic not their social impacts. So, governmental investments seek to support projects development which ensure the developers more profitable chances instead of renovating or improving cities' conditions like decreasing higher densities or services supply [7].

\subsection{Consequences of urban injustice}

The results of injustice are several not only economic inequalities like income or wealth distribution, but also there are disparities of opportunities, access to public services like health care, education and housing. If injustice problem does not be faced, inequality will increase year on year and this injustice increases and fuels conflict. It results in dangerous problems that disturb communities, changing social bonds, leading to social problems like exclusion, enmity, conflicts, wars, segregations and making very large gap between poor and rich people. So, we urgently need to get rid of injustice by applying proper public policy, increasing social responsibility and citizen awareness with sharing principle encouraging applying it. To solve injustice problem, new concepts and ideas like sharing principle that prevent injustice need to be applied [20].

\subsection{The key to reduce urban injustice.}

To reduce injustice, governments should encourage sharing principle in different fields like, sharing common data among institutions of country like information, statistics and education tools. And among different countries in the world, sharing principle also need to be increased through sharing research materials 
that are concerned to global issues. This became easier than before thanks to the worldwide web.

This principle is still adopted as a primary economic and social principle. For economic sharing principle, there is a movement appeared in Seoul, South Korea in 2012 that is called 'Sharing City'. This project is based on four goals: to decrease the resources usage, provide work chances, make renovation in societies and create communities free of pollution. We can share various utilities in our cities like parking spaces which are unused, empty accommodations, even our unneeded clothes or meals, books, internet access and open spaces of public institutions. This project results in a new culture thanks to government that provides city's spaces which are unused and encourages sharing model. Although this principle works within the capitalist system, it is shown that sharing concept is influencing thinking [20].

\section{- $\quad$ Sharing principle}

sharing principle urgently needs to be applied to reduce urban injustice. It is one of the most effective method to get rid of injustice problems to achieve justice and peace in societies. When someone shares things with other person, trust is generated, divisions are demolished, unity is created and as a result of this justice is achieved. Sharing principle is one of the most important tools to solve economic, social and environmental problems in cities. It is a call for love. If people are still living in unjust world, they will find their communities in harmony, and we cannot realize peace.

Injustice creates social problems that result in conflicts. So, injustice and anything leading to it in society should be gotten rid of, through consciousness and encouraging living a just life. [20]. Also, to achieve justice, the American Planning Association's Code of ethics 2005 should be applied. Its A section Principles called for; to apply social justice, choice and opportunity should be increased for all citizens, needs of disadvantaged must be satisfied, social and economic integration in the society should be improved [21].

\section{Conclusion}

The above discussions reveal that many cities all over the world suffer from urban problems like all kinds of injustice. This injustice is demonstrated in various social, economic, environmental dimensions and other ones. As a result of this urban injustice, social problems appear such as social segregation and exclusion that result in alienation, conflicts and higher crime rates. From economic perspective, there are economic disparities in opportunities, income level, jobs, wealth and resources distribution. And, from environmental perspective, there are disparities in quality of urban environment among areas of the same city. These disparities appear in pollution levels, access to green public spaces and quality of urban life.

There is also injustice in the distribution of public services in cities like education, healthcare, urban public spaces, public transportations, infrastructures and all other basic public services.

From just city point of view, if we want to classify areas within a city as just and unjust ones, we have to ask some instinct questions from several perspectives: social, economic, environmental, political and moral ones. To what extent there is involvement of citizens in the urban production process, public policy and decision-making activities? Do they have access to public spaces, services like, education, housing, health care, public transportation and economic opportunities? Are their community and public spaces homogeneity or diversity? Are benefits been distributed fairly for all classes? Is governance be decentralized?

From public services point of view, we can conclude some criteria through which we can measure justice / injustice within a city. Justice indicators deal with some measurements like the quantity and the quality of necessary public services such as: housing, education, health care, access to safe public spaces that support social interactions and so on as shown in (table 1).

Table 1. Some physical indicators of public services used to measure justice in areas within a city.

\begin{tabular}{|c|c|c|}
\hline Indicator & Sub-criterion & Source \\
\hline Residential & Housing & $\begin{array}{l}\text { Susan S. } \\
\text { Fainstein, John } \\
\text { Friedman [6] } \\
\text { John Rawls [7] }\end{array}$ \\
\hline Educational & $\begin{array}{l}\text { Primary, } \\
\text { secondary } \\
\text { school }\end{array}$ & John Rawls [7] \\
\hline Health care & $\begin{array}{l}\text { Hospital, } \\
\text { health centers }\end{array}$ & $\begin{array}{l}\text { John Friedman } \\
\text { [6] }\end{array}$ \\
\hline Urban public spaces & $\begin{array}{l}\text { Green public } \\
\text { spaces, urban } \\
\text { spaces, parks }\end{array}$ & $\begin{array}{l}\text { Henri Lefebvre, } \\
\text { Susan S. } \\
\text { Fainstein [6] } \\
\text { John Rawls [7] }\end{array}$ \\
\hline
\end{tabular}

Source: [5] edited by authors.

This paper concludes a definition for Just City, it is a city for all social classes and groups where all people 
should be integrated in political life, urban production and decision-making process. Where there is fair outcome distribution because public regulation works for all instead of working for elite classes. Everyone should have equitable access to all public services, opportunities and goods specially marginalized groups or minorities, to guarantee them fairness in opportunities, sufficiency of their essential human rights, and life without exclusion, conflicts or wars.

To move towards a more just world, environment should be respected and integrates with social, economic and other aspects. Also, rural-urban linkages through the relations between city and its region should be supported.

\section{Acknowledgements}

I would like to thank my professors in the Department of Architectural Engineering, Faculty of Engineering, Zaqaziq University, my colleagues specially Eng /Reem Okasha and my family specially my mother for their efforts. And everyone helping to finish this paper.

\section{References}

[1] Tadamun Initiative, "Justice in Planning Project", 2015 Available from: http://www.tadamun.info.

[2] Global Justice Index Report, 2016.

[3] Y. Dandurand and J. Jahn, " Access to Justice Measurement Framework Measurement Working Group1Technical Report", Series of Access to Justice BC, 2017.

[4] Z. Shah, M. Ahmad, Z. Marwat and N. Yousaf, "An Appraisal of Justice in Pakistan from the Prism of Platonic Justice", Research Journal of South Asian Studies Vol.32, No.1 pp.261-270, 2017.

[5] S. GHaedrahmatia, A. Khademalhoosinib and F. Tahmasebib, "Spatial Analysis of Social Justice in City of Isfahan", Annals of GIS Journal Vol.24, No.1 pp.1-11, 2018.

[6] P. Marcuse, J. Connolly, J. Novy, I. Oliv, C. Potter and J. Steil, "Searching for the Just City Debates in Urban Theory and Practice Book", Routledge, 2009.

[7] S. Fainstein, "The Just City Book", Cornell University Press, 2010.

[8] P. Nnodim, "The Question of Justice Book", ResearchGate, 2020.

[9] M. Gelobter, "The Meaning of Urban Environmental Justice", Fordham Urban Law Journal Vol.21, No.3 pp.841-856, 1994.

[10] J. Agyeman and B. Evans, "Just Sustainability': The Emerging Discourse of Environmental Justice in Britain?", The Geographical Journal Vol.170, No.2 pp.155-164, 2004.

[11] O. Yiftachel and R. Mandelbaum, "Doing the Just City: Social Impact Assessment and the Planning of Beersheba, Israel", Planning Theory \& Practice Journal Vol.18, No.4 pp.525-548, 2017.

[12] S. Campbell, "Sustainable Development and Social Justice: Conflicting Urgencies and the Search for Common Ground in Urban and Regional Planning" Michigan Journal of Sustainability Vol.1, pp.75-91, 2013.

[13] M. Garrido, "Social Sustainability in Metropolitan Areas: Accessibility and Equity in the Case of the Metropolitan Area of
Valencia (Spain)", Sustainability Journal Vol.371, No.10 pp.116, 2018.

[14] E. Burton, "The Compact City and Social Justice", The Housing Studies Association Spring Conference, 2001.

[15] Office of King County Executive Dow Constantine, "Equity and Social Justice Strategic Plan 2016-2022 Report", 2016.

[16] N. Ketprapakorn and S. Kantabutra, "Sustainable Social Enterprise Model: Relationships and Consequences", Sustainability Journal Vol.11, No.14 pp.1-39, 2019.

[17] L. Gilbert, "Social Justice and the Green City", Brazilian Journal of Urban Management Vol.6, No.2 pp.158-169, 2014.

[18] K. Lange, "Environmental Justice in Urban Area" article, 2014. Available from: https://www.academia.edu/30818768/Environmenta 1 Justice in Urban Areas, 2014.

[19] J. Rawls, "A Theory of Justice Book", Oxford University, 1999.

[20] G. Peebles, "The Shame of Injustice", article on Nation of Change online Magazine, May 2018. Available from:

https://www.nationofchange.org/2018/05/28/the-shame-of-injustice/\#, 2018.

[21] S. Moroni, "The Just City. Three Background Issues: Institutional Justice and Spatial Justice, Social Justice and Distributive Justice, Concept of Justice and Conceptions of Justice", planning Theory Journal Vol.19, No.3 pp.1-17, 2020. 